\title{
Knowledge as Light
}

\section{Ibrahim Kalin}

The question of knowledge presents itself as one of the most important issues for human thought and society because it is through knowledge that we establish a bond with God, ourselves, other human beings, the world, its meaning and purpose. We establish sociopolitical systems and civilizations on the basis of it. Defined as such, no society can dispense with knowledge. Knowledge, however, transcends the limits of social function and reveals something of the deepest nature of the human being. Our state of being-inthe-world and being-created-by-God is revealed to us in our knowledge of ourselves. More importantly, we do not simply exist but also know that we exist. It is this knowledge that enables us to make sense of the world, conceive it as an intelligible state of being, and realize our place and role in it.

Knowledge, however, is always the knowledge of something. Every meaningful statement is the affirmation or negation of something. In knowing a physical entity, a concept, or a feeling, we affirm or negate the existence of that "thing" which has become the subject of our knowledge. This "thing" and the "of" of our judgments ultimately hark back to the allencompassing reality of being, because what can be affirmed or negated cannot be other than being. In this regard, there is no knowledge that precedes being. Every cognitive act directed toward ourselves or other things that can be the subject of human knowledge is grounded in the all-inclusive and penetrating reality of being. This aspect of being has been called in Islamic philosophy the inbisāt al-wujud, "expansion of being," and sometimes al-sarayan al-wujüd, "penetration of being." In sharp contrast to the epistemologies of subjectivism, one is before one knows. Our existence always precedes our knowledge of it, even though the latter may effect and modify the former in a myriad of ways. Said differently, the reality of being is not exhausted in the deliverances of conceptual thought. ${ }^{1}$ 
The primacy of being over knowing suggests that one has to start with being ( wujūd) in order to be able to say something about knowledge ('ilm), its possibility, its conditions, its structure, its validity, and so on. As Dawud al-Qaysari, one of the prominent figures of the school of Ibn al-Arabi, says, "Being is the standing condition of knowledge." 2 Any epistemic act, regardless of its direction and content, takes place within a framework of meaning and intelligibility provided by the all-inclusive reality of being. Now, this is obviously the position of the ultimate primacy of existence (wujūd) over essence (mahiyyah) and, by derivation, over knowing ('ilm), which has been expounded by a great majority of Muslim metaphysicians. ${ }^{3}$ Despite its central importance, however, the close relationship between being and knowledge has been absent in modern Western philosophy thanks to the subjectivist philosophies of knowledge that give a resolute priority to the deliberations of discursive thought over and against our prediscursive existence. ${ }^{4}$ The catastrophic effects of the modern notion of human agency which is based on the different forms of subjectivist epistemology, such as rationalism and empiricism, are now all familiar to us in various segments of modern society in which we live. Positivism, humanism, individualism, scientism, imperialism, Orientalism, capitalism, and environmental crisis cannot be understood properly without realizing their deep roots in the seventeenth and eighteenth century conceptions of being, knowledge, and human agency. ${ }^{5}$

With a few (notable) exceptions, ${ }^{6}$ the contemporary Islamic world too suffers from the lack of a serious treatment of the question of knowledge in its relation to being and human agency. Despite all the rhetoric on the importance and indispensability of knowledge in Islam, there are only a few works of philosophical nature to which we can turn for a serious analysis of the subject. The contemporary Islamic world has not only abstained from an earnest encounter with the challenge of Western theories of knowledge, but it has also failed to bring out the immense wealth of traditional Islamic philosophy for the construction of a serious philosophical discourse. At this point, Mehdi Ha'iri Yazdi's book, which is analyzed in this essay, stands out as a ground-breaking attempt to bridge this gap and face the challenge of building a philosophical discourse based on the Qur'an and the principles of traditional Islamic philosophy. The scarcity of works of this kind attests to the necessity of stating and motivating the problem before we can undertake any full-fledged inquiry. This essay consists of two parts. In the first part, we state and motivate the question of knowledge 
as a philosophical problem, viz., knowledge-qua-knowledge and not simply knowledge as utility and power. The second part will concentrate on the book under discussion with an aim of providing a critical examination of the arguments of the author. There will be also an occasion to look at the possible domains of further research and study suggested by this introductory discussion on knowledge.

\section{Problem Stated: Knowledge as Fact/Power or Knowledge as Deliverance}

The modem notion of knowledge, one may argue for the sake of brevity, is based on two fundamental premises: knowledge as fact and knowledge as a power-generating medium. The first premise states that knowledge is a linguistic formulation describing the state of affairs as they are available to our sensory experience. In order to become the proper subject of knowledge, the world has to be constructed as a factual unity, each part of which constitutes a "fact." This is so because the statements about the external world are said to be true, according to the correspondence theory of truth, only when they correspond to "facts" that we encounter in the extra-mental world. Thus facts, it is presumed, exist antecedently and independently of thought, language, and, more importantly, values. The description of the world of physical entities as a conglomerate of "occurrences" and "events" is obviously another way of formulating the well-known naturalist notion that the external world, viz., the Cartesian res extensa can be couched in a language of pure quantities. ${ }^{7}$ This we may call the "entification" of reality.

Although the fallacy of Cartesian bifurcation has been brought out in numerous discussions and studies, ${ }^{8}$ it can hardly be claimed that the dualism of res extensa and res cogitans is a thing of the past. On the contrary, one can still see the repercussions of naturalism and subjectivism in natural sciences and various intellectual circles in the Western as well as in the Islamic world. Obviously, the relegation of knowledge to factual description completely obscures its existential dimension. Our relationship to knowledge is such that we cannot remain indifferent to veritable (haqq) or false (batil) knowledge. The acquisition of the knowledge of things, or what the Peripatetics call the intelligible form (al-surat al-aqliyyah) of intelligible substances, brings about a transformation by either elevating us to higher planes of existence or expanding our vision horizontally. One cannot remain, for instance, in the same state of existence and consciousness before and after one receives knowledge of the Divine. This holds true 
even for our daily experiences: We cannot be the same "person," that is, in the same mode of being and consciousness after hearing bad news that may change our whole perception of ourselves and the things around us. ${ }^{9}$ Knowledge as factual report is true and legitimate only if we accept the model of machine as a valid way of explaining the reality of which we are a part. In this case, however, we cannot make sense of the well-known prayer of the Prophet of Islam: Allahumma arina haqa'iq al-ashya' kama hiya.

The second definition of knowledge, as a source of power and control, can be taken as a corollary of the first view. It is self-evident that a domain of existence, such as the world of nature, should be the subject of control and manipulation if it is deprived of any Divine or human quality and construed as no more than a mass of "brute facts." 10 Knowledge as a way of conquering the world is so deeply rooted in the consciousness of modern thought that we often associate the value of knowledge with its socioeconomic and political function: Knowledge is something noble for us not because it helps us unveil the meaning of the world but because it helps us control the world. ${ }^{11}$ Knowledge is indispensable for us not because we realize ourselves in and through knowledge but because we can use it to dominate the other. ${ }^{12}$ Even when it is used for the good, we still appeal to knowledge as social utility by relegating it into a process of societal construction. That is why it is the sociology, rather than the metaphysics, or philosophy of knowledge, that concerns us most in our discussions of knowledge.

This is, of course, not to deny altogether the social function of knowledge. It should be emphasized, however, that knowledge as a social construction cannot account for the philosophical, metaphysical, and spiritual dimensions of knowing which, when understood as light (nur) and deliverance (najat), provide a key for transcending the merely human and realizing the Divine. As we have stated earlier, our being-in-the-world precedes our knowledge of it, and this means that we know the world through our mode of being, not vice versa. In other words, the way the world as an intelligible structure reveals itself to us is enmeshed in the way we reveal ourselves to the world. It is, then, impossible to develop a philosophical discourse on knowledge without realizing the ontological issues involved.

The primacy of ontology and metaphysics over epistemology and methodology can be taken as a counterexample of subjectivist and humanist epistemologies that privilege the mental image of reality over the pre- 
discursive reality of things. The antisubjectivist notion of knowledge, however, does not see the knowing subject as the sole creator of knowledge and meaning. It is obvious that when we accept the human mind as the primary abode of meaning and significance, we claim, knowingly or not, that the world in and of itself is devoid of meaning and that intelligibility is something we, as knowing subjects, assign to the world. Here meaning, it is assumed, occurs in our subjective consciousness whether we consider the objective existence of the world as a necessary condition of intelligibility or not. By contrast, the antisubjectivist position, which can be seen as an extension of the primacy of existence (wujūd) over essence (mahiyyah), accepts the extra-mental world as a standing condition of knowledge and intelligibility. It is true that meaning is cultivated and formulated in our minds through rational processes. It is also true that we express this meaning in language. But this is possible only when we intend to the world which is the subject of our knowledge. If it were possible for us to generate meaning about the world in isolation from the reality of the world itself, it would then be possible for us to do it even without knowing it. This is evidently an absurd conclusion. The only possible way of "making sense" of the world is to "unite" our mind and soul, to use Peripatetic language, with the intelligible structure of the world.

The point that the foregoing argument tries to make becomes more evident when we look at our knowledge of the Divine and other human beings. Meaning is something given (wahbi and not kasbi or husüli, if one wants to use classical terminology) insofar as the Divine realities are concerned. Although we, as free human agents, have a variety of ways to cultivate, transform, and actualize this meaning, we cannot claim to be the sole locus of such meaning. At another level, the same principle holds true for the meaning that other human beings have for us: we do not think, or at least should not think, of other human beings as devoid of meaning and value before we turn them into an "object" of knowledge. The world of the "other" cannot be construed merely as dependent on our perception of it.

\section{Knowledge as Presence}

Before delving into a critical analysis of Yazdi's book, The Principles of Epistemology in Islamic Philosophy, it is important to understand the significance of his undertaking. In our ordinary experience of the world, the world presents itself as the primary subject of knowledge. We intend to the world through our mind, consciousness, reason, language, and so on. But 
our intentional acts are addressed to the world without necessarily containing an account of the knowledge of ourselves. A closer examination, however, reveals that self-knowledge always precedes the knowledge of the external world. In other words, we cannot know the world without knowing or being conscious of ourselves. As rational animals (haywan nātiq), we can never be bereft of some sort of consciousness of ourselves, whether this consciousness is of the highest order or not. Ibn Sina's famous metaphor of "flying man" seeks to prove exactly this point: Even in a purely spiritual state of being where a human being is stripped of all of his physical qualities such as hearing and seeing, he cannot cease to have some kind of awareness of himself. ${ }^{13}$ Suhrawardi highlights the same point by saying that "you are never unconscious of your essence (dhatuka) in both sleep and waking." ${ }^{14}$ At this point, it is apparent that self-knowledge not only precedes the knowledge of the external world but also makes it possible. It is also clear that our knowledge or awareness of the world is always mediated through our self-knowledge. It is for this reason that Suhrawardi, along with Mulla Sadra, gives priority to self-knowledge which is presential (al'ilm al-hudüri) over the knowledge of the external world which is representational (al-'ilm al-husüli al-irtisämi). ${ }^{15}$ Since we know our "essence" as a result of the unity, the intellect/knower ("aqil) and the intelligible/known ( $m a^{\prime} q u l$ ) and not through the medium of representation, self-knowledge is "necessary" (wäjib) whereas the world is known "accidentally" (bi al'arad). ${ }^{16}$ In other words, the knowledge of the self precedes the knowledge of the external world in an essential way.

The primacy of self-knowledge has also been accepted in Western philosophy, so much so that the most prominent Kantian of this century describes it as the "highest aim of philosophical inquiry."17 Here, we can see the importance of Yazdi's task: the a priori knowledge of the self informs our knowledge of the world. ${ }^{18}$ Therefore one has to start with the self in order to know that which is other than the self. Yazdi, following the tradition of illumination (ishräq), calls the knowledge of the self "knowledge by presence" (al-ilm al-hudüri) because, in this special kind of knowledge, the object of knowledge is "present" in the subject. In other words, there is no object-subject "dualism" nor is there any room for separation between that which knows (i.e., the intellect) and that which is known (i.e., the intelligible). ${ }^{19}$ This is the celebrated doctrine of the unity of the intellect, intelligence, and the intelligible. ${ }^{20}$ 
Although the importance of self-knowledge is evident to those who are seriously interested in the philosophical roots of our knowledge of the external world, this can hardly be said to be the case for many. Therefore, it is not enough to state the problem. One has to motivate the problem also. This, I think, can be seen as a drawback of Yazdi's work, not because the book itself fails to incite interest in the subject but because the philosophical discourse current in the Islamic world lacks a serious and deep investigation of the question of self-knowledge. Accordingly, one would expect a convincing exposition of the raison d'etre of this enterprise before one is invited to take up the issue with serious interest.

Going back to the book itself, the primacy of self-knowledge and its nonrepresentational nature is the first important thesis of Yazdi's work. Clearly, sense-perception does not permit any schism or vacuum between the subject and the object because, as Yazdi convincingly shows, to say that I know that I am in pain is essentially the same as saying that I am in pain. The existential unity between the knower and the known marks the very nature of sensual knowledge with which the empiricists also agree. In other words, sensual knowledge represents the prime example of knowledge by presence which is based on the presence of the intelligible in the intellect. Yazdi goes one step further and claims that knowledge by presence is not confined to sensual knowledge but in fact informs also intellectual knowledge. Since intellectual knowledge is essentially a vision (mushähada), taste/experience (dhawq) and realization according to the school of Illumination, the "intelligibilia" are also known through knowledge by presence. But how does one do this? In other words, how are we able to know the intelligibilia (máqulät) with the same degree of certainty and precision with which we know the "sensibilia" (mahsusāt)? We know that some Muslim metaphysicians have claimed that it is possible to have an unmediated knowledge of intelligible substances. ${ }^{21}$ It is not, however, clear from Yazdi's account if he provides any cogent argument to prove this point.

The second problem, which issues from the first one, is the question of solipsism and the ontological status of the intelligibles. If it is possible to know the intelligible substances via knowledge by presence, does this mean that the human mind can know them because they are present in and only in the mind? If this is granted, will we not be trapped in some sort of solipsism because we seem to take the intelligible substances as the intrinsic qualities of the mind? In other words, if knowledge by presence is to be 
extended to the ma'qulatt, does this mean that we construe the intelligibilia as nothing other than the contents of the human mind? How can we avoid the danger of reducing knowledge to "establishing relations between ideas" as Hume, for instance, would say?22 In light of these remarks, we have, it seems, one of two options: either we have to admit that knowledge by presence does not apply to the knowledge of intelligible substances on the one hand and to the external world on the other, or we have to say that the mind can know the intelligibilia through its intrinsic qualities. The last assertion, though not clear in Yazdi's account, may very well conjure up the idea that the mind is the proper place of the intelligibility of the world and that the world as such does not have an intelligible structure in and of itself. ${ }^{23}$

The third problem is the question of the immediacy of knowledge: Is there a knowledge that is not mediated through concepts, thought process, or language? ${ }^{24}$ In sense perception, we do not appeal to concepts or notions to experience our state of being. Although we use language and words to express our experience, this linguistic intrusion, so to speak, is something a posteriori rather than a priori to the experience itself. But is this also true for the intellectual knowledge, or our knowledge of the Divine? The relevance of this problem to Yazdi's discussion is obvious: If knowledge by presence is primarily an unmediated form of knowledge, how is it possible to have an immediate and unmediated knowledge of the intellectual substances? This is one of the key problems for any discussion of the epistemology of mysticism. ${ }^{25}$ Although Yazdi provides a well-informed discussion of mysticism, he does not address this fundamental question.

The application of knowledge by presence to God's knowledge of the world and our knowledge of Him is another major theme of the book. Although the chapters devoted to the discussion of this important issue give us a number of insights into the metaphysical significance of knowledge by presence, Yazdi's analysis of "emanation" presents some difficulties. First of all, the author translates "emanation" for $i b d a^{4}$ which is, properly speaking, "creation" or "making" rather than emanation. The word "emanation" has usually been associated with the Peripatetic school in the Islamic world. Farabi's and Ibn Sina's detailed discussions of this concept rest on the words șdür and fayd rather than $i b d a^{6}$. In addition to this, Yazdi's concept of "emanation" does not seem to follow the Peripatetic tradition in that his understanding resembles "creation" in the generic sense and not emanation in the specific (viz., mashshai) sense of the term. It is, I believe, important 
to clarify these concepts in conjunction with other terms that have been used for the origination of the world such as ihdath, khalq, and takwin.

The other related problem is the apparent parallelism created between emanation and "absorption." Yazdi posits emanation and absorption as the two poles of the hierarchy of being. Emanation signifies the fact that "a pure light of existence has issued forth from the principle of reality" (p. 134). Absorption, on the other hand, expresses the same fact from the other side of the pole, i.e., from the point of view of created beings. This principle of the school of illumination accounts for the illuminative relationship (idafah ishraqiyyah) between the principle and the manifestation. Nevertheless, Yazdi's analysis, despite its depth and precision, does not contain a discussion of the conditions of "absorption" as an ontological and metaphysical state. One question to be asked at this point is how this absorption takes place. Said differently, is it enough for us to be created or "emanated" from the principle in order to be absorbed in it?

In order to prevent any misunderstanding, I would like to draw attention to a prima facie paradox in Yazdi's discussion of annihilation (fana'). Yazdi's account of absorption as a mystical state does not contain a clear and well-articulated discussion of agency, and thus one suspects if the state of absorption is attained innately or by meeting certain a priori conditions such as intellectual understanding, spiritual discipline, and moral behavior. At the end of chapter nine, however, he depicts annihilation as "an intentional process of purification that a mystic quite consciously undertakes" (p. 158). And he goes on to say that the "culmination of this process is knowledge by presence which is never representational." Now, it is not clear how such an "intentional" act results in knowledge by presence. The second problem which seems to contradict the previous judgment is the nature of such knowledge: Does a mystical experience of this kind remain nonrepresentational when it is carried out by the intentional effort of the mystic? If so, then does this mean that the intentions can also be "unmediated" and have a status of disengagement?

\section{Concluding Remarks}

These questions can be multiplied and in fact should be multiplied in order to have a healthy and well-thought discourse on knowledge. As the question of self-knowledge entails the discussion of such fundamental issues as epistemological justification, human agency, mystical experience, and the status of the external world, we cannot look for any shortcuts to 
resolve the lingering intellectual problems of the Islamic world by making hasty generalizations about the subject. In this regard, the task that Yazdi has set out to accomplish is a monumental one, and the merit of his book is not jeopardized by the score of questions and objections we can raise against it. The contemporary Islamic world desperately needs to develop a philosophical discourse that will enable it to cope with the intellectual challenges of the modern world on the one hand and its own philosophical tradition on the other. I believe that Yazdi has made an important contribution toward the realization of this goal.

\section{Notes}

1. When translated into religious language, this principle states that the reality of God, the Infinite, the Perfect, is neither exhausted nor encapsulated in our formulations of Him whether such descriptions are carried out in the language of transcendence (tanzih) or immanence (tashbih). The Qur'an contains many verses emphasizing the infinite transcendence as well as closeness of God.

2. The occurrence of knowledge (husul al-'ilm) in every knowing subject comes about only by means of it (i.e., Being). Dawud al-Qaysari, "Al-Muqaddimat," in Al-Rasail, ed. by M. Bayraktar as Davud el-Kayseri, er-Resail (1997), 31.

3. Although Suhrawardi's essentialist metaphysics represents a special case along with that of kalam, the falasifa, the school of Ibn Arabi, and later Ishraqiyyun such as Mulla Sadra and Sabziwari who interpret Suhrawardi's metaphysics of essences in the light of the primary of being (așalat al-wujūd) have brought out the philosophical significance and implications of this doctrine in a number of seminal works. See, inter alia, Dawud al-Qaysari, Al-Muqaddimat, especially pp. 26-75; Sadr al-Din al-Shirazi, alHikmat al-Muta'aliyah fi'l-Asfar al-Arba'ah al-'Aqliyyah, ed. by M. Rida al-Muzaffar, (Beirut, 1981), especially vol. 1, part 1, and Kitab al-Masha'ir, ed. by H. Corbin, Le Livre des Penetrations Metaphysiques (Tehran, 1982), part 1. In English, the best introduction to the subject is without doubt the masterly analysis of T. Izutsu, in his The Concept and Reality of Existence (Tokyo, 1971), especially Chapter 4. See also S.H. Nasr, "Existence (Wujud) and Quiddity (Mahiyyah) in Islamic Philosophy," Iqbal Review, October 1989-April 1990: 161-194; Nasr, "Post-Avicennan Islamic Philosophy and the Study of Being," International Philosophical Quarterly XVII, no. 3 (September 1977): 265-271.

4. The only exception to this is the revival of Thomism along with Heidegger who of course differs completely from the Thomistic perspective. In the first part of this century, a number of Christian thinkers have undertaken a grand-scale project of reviving Thomistic philosophy under the intellectual leadership of Etienne Gilson. One of the central themes of this movement is the primacy of esse over quidditas as we can see in the fecund scholarship of Gilson. See, for instance, Etienne Gilson, Being and Some Philosophers (Toronto, 1952) which has also many references to Islamic philosophers despite the fact that Gilson's interpretation of Ibn Sina is based on a number of "Thomistic" misunderstandings. See also Jacque Maritain, Existence and the Existent (New York, 1950) and the important work of William E. Carlo, The Ultimate Reducibility of Essence to Existence in Existentialist Metaphysics (The Hague: Martinus Nijhoff, 1966).

5. An excellent treatment of this important subject can be found in Charles Taylor's Sources of the Self: The Making of the Modern Identity (Cambridge: Harvard University Press, 1989). In this century, it was the arduous task of Martin Heidegger to reassert the primacy of Being over the knowing subject in Western philosophy. Unfortunately, we have no space here to go into the importance as well as the subtle dilemma of Heidegger's 
project of Being which is rooted, despite Heidegger's unflinching anti-humanism, in a semi-humanism because of its breakaway from the Divine.

6. The most important work to be cited by S.H. Nasr's Knowledge and the Sacred (New York: SUNY, 1989) where Nasr gives a very profound treatment of knowledge as deliverance. In addition to this seminal work, mention should also be made of Naquib alAttas's Prolegomena to the Metaphysics of Islam (Malaysia: ISTAC, 1995) which contains an excellent summary and study of Ghazzali's Ma'arij al-Quds fi madarij ma'rifat al-nafs. Although this is not the place to delve into a critique of the Islamization of knowledge project, one can say that the most conspicuous flaw of this project, as it is formulated today, stems from its confusion of knowledge with social sciences and displines which constitute only a subcategory of knowledge.

7. The Wittgenstein of Tractatus states that "the world is the totality of facts, not of thing." This statement can be seen as the pinnacle of the reduction of the world into atomistic facts. Although the Wittgenstein of Philosophical Investigations has declared Tractatus as intrinsically wrong, its ramifications can still be seen in the annals of Analytic philosophy. For a critique of Analytic philosophy from this point of view, see Ernest Gellner, Words and Things (Penguin Book, 1968), especially pp. 133-175 where Gellner makes the bold claim that "Linguist philosophy has no theory of knowledge, but only ... a theory of why the theory of knowledge is redundant and impossible."

8. There is a vast and rapidly growing literature on the Cartesian dualism and its consequences. Voices have been raised from right to left to show the incoherence of the Cartesion bifurcation on the one hand, and the ways to overcome it, on the other. See, among other works, Wolfgang Smith, Cosmos and Transcendence Breaking Through the Barrier of Scientistic Belief (Illinois: Sherwood Sugden \& Company, 1984); Seyyed Hossein Nasr, Religion and the Order of Nature (Oxford: Oxford University Press, 1996); and Etienne Gilson, The Unity of Philosophical Experience (New York, 1941), expecially Part 2. Richard Rorty attributes the "invention of the mind" to Descartes and his cogito which, as he shows convincingly, lays the foundations of modern theories of knowledge and the ill-formulated mind-body problem. See his Philosophy and the Mirror of Nature New Jersey: Princeton University Press, 1979), $17 \mathrm{ff}$.

9. The knowledge of the doomsday to which the sacred book (the Qur'an) has so many references can be understood in the context of the transforming nature of knoweldge. The dazzlingly vivid description of the day of judgment in the sacred text is meant to bring about an inner transformation in man's soul here and now, thus suggesting a "presential" effect for knowledge.

10. This is the view of nature that came into being with the scientific revolution of the 17th and 18th centuries. Francis Bacon's Novum Organum and the view of nature espoused in his other works can be said to be the precursors of the idea of knowledge as power and domination over nature. The disastrous consequences of the view of knowledge as power which goes hand in hand with the mechanization of the world have been analyzed in various studies. See Nasr, Religion and the Order of Nature, and Man and Nature: The Spiritual Crisis in Modern Man (ABC International Group, 1997), 51-80; also Philip Sherrard, The Rape of Man and Nature (Golgoonoza Press, 1987), especially Chapters 3 and 4.

11. This aspect of knowledge as power has been analyzed most vigorously by Michel Foucault, especially in his Surveiller et Punir (1975). Although Foucault's notion of power is fatalistic and as such has received a number of justified criticisms, his work offers a very diligent examination of knowledge as power in modern society.

12. As we all know too well, the perfect example of knowledge as intellectual hegemony is the case of Orientalism as Said has shown convincingly in his Orientalism (1979). Strangely enough, a new wave of Orientalism in reverse, that is some sort of Occidentalism is becoming a common sense in the Islamic world. After all, we have a book by Hasan Hanafi with the title of Muqaddimah ila 'ilm al-istighrab.

13. What is excluded from the mind here is physical "accidental" existence and not being as such. We feel it necessary to say this lest we fall into some sort of idealism by developing an idea of "pure consciousness." As conceived by modern rationalism, pure conscious- 
ness is not a possibility because, according to the primacy of being (asalat al-wujüd), what we call "abstract or detached consciousness" is itself a mode of being in the hierarchy of gradation (tashkik). Even in its abstract awareness of itself, the intellect conceives itself as an actual and meaningful being within the context of intelligibility provided by something other than the human mind.

14. Suhrawardi, Talwihat, Physics, fol. 60, quoted in Hossein Ziai, Knowledge and Illumination: A Study of Suhrawardi's Hikmat al-Ishraq (Atlanta: Scholars Press, 1990), 147. See also the quote from Hikmat al-Ishraq in Yazdi, pp. 83-84.

15. See, Ziai, ibid., 142ff.

16. It is this elusive point in knowing "by necessity" or "by accidence" that causes confusion. Fazlur Rahman, for instance, interprets Sadra's explanation of the knowledge of the external world as "extremely unsatisfactory" because he reads Sadra's epistemology as a form of subjective idealism. See his The Philosophy of Mulla Sadra (SUNY, 1975), p. 224. Sadra, on the other hand, clearly states that it is in the nature of the self to know itself primarily and essentially whereas the knowledge of the external world is based on the subjectobject predication. See Sadra, Asfar, I, 3, pp. 297-99. Yazdi also makes this point clear. See The Principles of Epistemology in Islamic Philosophy: Knowledge by Presence (SUNY, 1992), pp. 31-32 and 85-86.

17. Ernst Cassier, An Essay on Man (New York: Bantam Book, 1970), 1.

18. Yazdi, 54ff.

19. According to Plotinus, self-knowledge overcomes the representational gap between the knowing subject and the object known, thus leading to the elimination of epistemological distance between the two. For Plotinus's position on this, see S. Rappe, "Self-knowledge and Subjectivity in the Eneads," in The Cambridge Companion to Plotinus, ed. by Lloyd P. Gerson, (Cambridge: Cambridge University Press, 1996), 255-274.

20. The current formulation of this notion goes back to Aristotle, De Anima, 430a where he says that "In the case of objects without matter, that which thinks and that which is being thought are the same, for theoretical knowledge and its knowable object are the same." See De Anima, translated by H.G. Apostle as Aristotle on the Soul (The Peripatetic Press, 1981), 51. Like the distinction between essence and existence, however, Aristotle falls short of bringing out the philosophical significance of this formulation. In the Enneads $V$, Plotinus gives a very profound explanation of this doctrine. The Plotinian restatement of the problem has been used widely by Muslim philosophers even though the name of Plotinus (Eflutin) rarely appears in classical sources. For the influence of the school of Alexandria, see, for instance, Sadra's treatise called Ittihad al-'aqil wa al-ma'qul in Majmua-yi rasail-i falsafi-i Sadr al-Muta'allihin, ed. by Hamid Naji Isfahani (Tehran: Intisharat-i Hikmet, 1996), 64-103. Note that the subtitle of the first chapter of this treatise is "Fi darajat al-'aql al-nazari muwafiqan lima zakarahu Iskandar al-Afridusi." Some scholars, however, claim that the unity of the intellect and intelligeable can be traced back to various passages in Phedon, Timaeus and the Republic where a "solidarite d'existence" is established between the Ideas and our soul. For a well-informed essay on this subject see, J. Pepin. "Elements pour une histoire de la relation entre l-intelligence et l-intelligible chez Plato et dans le neoplatonism," Revue Philosophique 81 (1956): 39-64.

21. Suhrawardi and Mulla Sadra are among the leading advocates of this view. For an extensive analysis of this subject, see the important work of Muhammad Fanaei Eshkevari, 'Ilm-i huzuri (Iran: The Imam Khomeini Education and Research Institute, 1996).

22. As I have tried to argue in the first part of this essay, knowledge cannot be seen simply as a "relationship" that occurs between an object and a subject. Such a relationship is made possible by a larger framework of intelligibility that goes beyond the human mind. It is by virtue of being "existent" (mawjud) that we are able to create such a relationship. In this regard, the ontological status of intelligible substances, or Platonic Forms, if you like, cannot be reduced to or deduced from the mind. This can be taken to be another instance of the primacy of Being.

23. It would not be out of place to note an implicit nominalism in Yazdi's following statement when discussing the question of definition: "This is called, in the Islamic system of 
philosophy, the method of "composition" (tarkib), meaning that we must construct the universal ideas of our definitions by way of combining or making a composition of empirical similarities and differences. In this system, all universal concepts must be obtained from and warranted by empirical exemplifications, and no pure $a$ priori concept is deemed valid or relied on" (70). I admit that I am not clear about the philosophical implications of this assertain that Yazdi attributes to Ibn Sina.

24. One of the earliest formulations of this can be found in Cratylus (438 a-d) where Socrates asks if it is possible to know things without names. "Name" (onoma) is, for Socrates, a representation of the essence of things. Understood as such, the essence of things precedes naming, and consequently one may arguably read Cratylus to mean that it is possible to know things without the mediation of names, i.e., concepts, notions, etc.

25. There is a good number of works on the possiblity or impossibility of unmediated knowledge. Those who reject the possibility of unmediated knowledge and experience of any kind claim that every cognitive act is informed by an array of epistemological and linguistic factors that are ever-present in such experiences including mystical experience. Therefore, there is no such thing as "pure experience." Those who accept the possibility of unmediated knowledge claim that such linguistic and cultural determinants come after, not before, the mystical experience. The most evident proof of this is the universality of mystical experience across the various religious worlds. The mystical experience of a Sufi and a Christian mystic differs in their formulation. But they cannot be said to be experiences of different things otherwise we would not be able to talk about such a thing as mysticism. For a staunch defense of the first position, see Steven Katz, "Language, Epistemology, and Mysticism" in Mysticism and Philosophical Analysis, ed. by Steven T. Katz (Oxford: Oxford University Press, 1983), 3-60. For a critique of Katz's position, see Sallie B. King, "Two Epistemological Models for the Interpretation of Mysticism," Journal of the American Academy of Religion LVI, no. 2 (Summer 1988): 257-279. For an interesting discussion of the subject, see also Robert K.C. Forman, "Mystical Knowledge: Knowledge by Identity," Journal of the American Academy of Religion LXI, no. 4 (Winter, 1993): 705-738. 